\title{
GCU
}

Glasgow Caledonian

University

University for the Common Good

\section{A comparative study assessing the wear behaviour of different ceramic die materials during superplastic forming}

Gomez-Gallegos, A. A.; Farrell, M.; Zuelli, N.; Staiano, A.

Published in:

Materialwissenschaft und Werkstofftechnik

DOI:

10.1002/mawe.201700044

Publication date:

2017

Document Version

Author accepted manuscript

Link to publication in ResearchOnline

Citation for published version (Harvard):

Gomez-Gallegos, AA, Farrell, M, Zuelli, N \& Staiano, A 2017, 'A comparative study assessing the wear

behaviour of different ceramic die materials during superplastic forming', Materialwissenschaft und

Werkstofftechnik, vol. 48, no. 10, pp. 983-992. https://doi.org/10.1002/mawe.201700044

\section{General rights}

Copyright and moral rights for the publications made accessible in the public portal are retained by the authors and/or other copyright owners and it is a condition of accessing publications that users recognise and abide by the legal requirements associated with these rights.

Take down policy

If you believe that this document breaches copyright please view our takedown policy at https://edshare.gcu.ac.uk/id/eprint/5179 for details

of how to contact us. 


\section{WILEY-VCH}

Article type: Article

Title:

A comparative study assessing the wear behaviour of different ceramic die materials during superplastic forming

\section{Titel:}

Eine Vergleichende Studie zur Bewertung des Verschleissverhaltens Unterschiedlicher Keramischer Materialien für Formwerkzeuge Während Superplastischer Umformprozesse

Authors: Ares A. Gomez-Gallegos ${ }^{1 *}$, Andrea Staiano ${ }^{2}$, Mark Farrell ${ }^{1}$, Nicola Zuelli ${ }^{1}$

*Corresponding Author E-mail: ares.gomez-gallegos@strath.ac.uk

${ }^{1}$ Advanced Forming Research Centre, University of Strathclyde, Inchinnan, PA4 PLJ, UK

${ }^{2}$ Design, Manufacture \& Engineering Management, University of Strathclyde, Glasgow, G1 1XJ, UK

Abstract:

Superplastic forming is an advanced manufacturing process where metallic sheets are heated to their superplastic region to be then blow formed within a die set. The process allows for the forming of complex parts but it is typically restricted to low volume production and high value pieces. Despite their brittle nature, ceramic dies 


\section{WILEY-VCH}

are a developing technology for Superplastic forming as they offer lower production costs and shorter lead times than conventional metallic dies, thus reducing process costs. This work presents a method to assess ceramic die wear by means of a novel test rig developed at the Advanced Forming Research Centre where the Superplastic forming die-part interaction can be replicated at laboratory scale. Controllable normal load tests at standard Superplastic forming conditions on three different reinforced ceramic materials are carried out with a view to understanding their wear mechanisms and to ultimately identify methods to improve their wear resistance.

\section{Abstract:}

Superplastische Formgebung ist ein fortgeschrittenes Herstellungsverfahren, bei dem metallische Bleche auf ihren superplastischen Bereich erhitzt werden, um dann in einem Formwerkzeugsatz geblasen zu werden. Das Verfahren ermöglicht die Herstellung von komplexen Bauteilen, ist jedoch typischerweise auf geringe Stückzahlen und hochwertige Teile beschränkt. Trotz ihrer spröden Beschaffenheit stellen Keramikwerkzeuge eine aussichtsreiche Technologie für Superplastische Formgebung dar, da sie niedrigere Herstellungskosten und eine kürzere Herstellungsdauer als herkömmliche Metallwerkzeuge bieten und somit die Prozesskosten senken. Diese Arbeit stellt eine Methode zur Bestimmung des Verschleißes von Keramikwerkzeug mittels eines neuartigen Prüfstands vor, welcher im Advanced Forming Research Center entwickelt wurde und in dem die Wechselwirkung von Formwerkzeug und Bauteil im Labormaßstab nachgebildet werden kann. Es wurden kontrollierbare Test unter Normalbelastung und unter üblichen Superplastische Formgebung-Bedingungen für drei verschiedene verstärkte keramische Materialien durchgeführt um deren Verschleißmechanismen zu 


\section{WILEY-VCH}

verstehen und letztlich Methoden zur Verbesserung der Verschleißfestigkeit zu identifizieren.

Keywords: Superplastic forming; ceramic, wear; tribology, friction, ceramic die. Schlüsselwörter: Superplastische Formgebung; Keramik, Verschleiß; Tribologie, Reibung, Keramikwerkzeug.

\section{Introduction}

Superplastic forming is a manufacturing process based on the ability of certain materials to undergo large tensile strains prior to failure when heated to high temperatures, typically over half the absolute melting temperature of the alloy [1]. For Superplastic forming processes, relative low gas pressure (10-30 bars) is injected to blow form single or multisheet metal components [2]. Due to the high temperatures involved (between $500^{\circ} \mathrm{C}$ and $900^{\circ} \mathrm{C}$ for aluminium and titanium alloys respectively), the materials for the Superplastic forming tools are limited to those resistant to high temperature creep and thermo-mechanical fatigue. Additionally, these materials should be non-reactive, or should be able to be prevented from reacting [3], [4].

Metal dies are the most commonly used in the SPF industry. High-alloyed nickelchromium stainless steels, such as Cronite HR4, ZG35Cr24Ni7Si, GX30NiCr39-24 or GX45NiCr49_27 [3], [5], [6], are typically selected for these tools. The use of metallic tooling is associated with two major costs: production time scale costs (long lead times) and non-recurring tooling costs (design changes or corrections) [2], [7].

Ceramic materials have been identified as a viable option for Superplastic forming dies due to their resistance to high temperatures, oxidation/reaction passivity, and 


\section{WILEY-VCH}

easy manufacturing characteristics. Moreover, ceramic dies can be manufactured from low-cost base materials, have a short lead time (3-6 weeks as opposed to several months of metallic dies), and usually do not require additional machining to ensure good surface finish after casting, hence reducing tooling and production time costs. However, current ceramic dies are limited by their short lifespan, since they are prone to fracture at low strain and surface degradation [1], [2], [7].

Brittle fracture is the dominant failure mechanism for ceramic materials. Ceramics observe very little plasticity and high crack growth rates. The crack initiation takes place where a local stress raises, which means there is a defect in the material structure, such as porous and change in the matrix mixture, or in the material geometry, such as corners and edges. Ceramic materials are also susceptible to fatigue, which is the deterioration and fracture of the material due to only cycle loads [8].

The use of ceramics for Superplastic forming has been studied since the 1990s. In 1992, Yaofu, G. et al. [9] presented a refractory concrete die for SPF of aluminium satellite dishes. Later, the Boeing Company [10] patented stand-alone ceramic dies. These dies were set onto a press platen and used practically in the same way as metallic dies. The ceramic material employed was from the group including Pyromedia HS2, Thermosil 120, and Thermosil 220. Jocelyn, A., et al., [4] in 2001 used low cost, disposable ceramic liners for fabricating SPF and diffusion bonding tooling. The ceramic used in this work was an alumina based feedstock (CT9), with a binder and a bonding agent (Secar 71 and PVA respectively). Good results, in terms of geometric accuracy of the formed part and no thermal creep nor linear deformation 


\section{WILEY-VCH}

of the moulds, were achieved in these experiments. However, the ceramics used for this SPF tools had relatively low fracture toughness which made them useful only for very short production or prototyping (short lifespan).

Reinforcements in ceramic materials aim at prolonging the life of the ceramic dies by controlling the stresses experienced by the tool or avoiding the propagation of the cracks and subsequent failure [1], [7]. For industrial applications, reinforcement techniques such as core material treatments or introduction of reinforcements within the die, i.e. rods, particles, or long/short fibres, had demonstrated to toughen the ceramic dies, extend their lifespan and enhance their mechanical properties [1], [2], [7]. For example, the Boeing Company solved the problem of premature cracking of dies by adding in the casting high-strength (1300 MPa) reinforced rods. These rods were made of fused silica oxides of silicon or alumina [1], [7]. This technology was patented by the Boeing Company in 2001. In 2007, Bernhart, et al. [11] developed a refractory castable reinforced with short metallic fibres. The use of short metallic fibres demonstrated to prevent catastrophic failure during the superplastic forming process. The material used was a geopolymer (alumino-silicate oxide, thermal silica fume and aqueous solution of potassium polysilicate) reinforced with $1.5 \mathrm{vol} \%$ (volume percentage) of AISI 310 stainless steel metallic fibres $(0.38 \mathrm{~mm}$ diameter and $12.5 \mathrm{~mm}$ length). By 2013, Bernhart [12] had successfully designed, manufactured and tested under industrial conditions, metallic fibre reinforced refractory castable dies for Superplastic forming of TA6V sheets. Lately, Deng, Y. et al. [13] presented a work where two temperature-dependent fracture strength models for fibre reinforced ceramic dies were developed. 


\section{WILEY-VCH}

Research in the Advance Forming Research Centre of the University of Strathclyde,

Scotland (United Kingdom) is currently being conducted to further investigate the use of ceramic materials for SPF dies. In the work presented in this paper, three commercial reinforced ceramic materials were mechanically tested with the aim of evaluating their wear behaviour when subjected to Superplastic forming representative conditions and assessing their suitability for Superplastic forming dies.

\section{Materials and Experiments}

\subsection{Materials}

Three commercial reinforced ceramic materials have been selected for testing and comparison:

i) a fused silica ceramic material reinforced by freeze casting;

ii) a fused silica ceramic reinforced with particle;

iii) a refractory castable ceramic reinforced with metallic fibres.

\subsection{Die Part Interface Rig}

A purpose built experimental equipment, a die-part interface rig, used for these experimental trials was designed and built at the Advanced Forming Research Centre in order to test the interaction between the die and the metal sheet during the Superplastic forming process. The rig features two stacks which can hold interchangeable tools. The tools can be either a metallic/ceramic die or a sample holder. A cylindrical furnace is fitted around the rig wrapping the stacks and the sample. The system can heat up to $1000^{\circ} \mathrm{C}$, and it is driven by a control software where the parameters of the trials can be set and measured during the process. Additionally, the rig is equipped with a thermal camera, Land Instruments FTI-E 1000, 


\section{WILEY-VCH}

which records in situ thermal images of the tool/sample when loading and unloading the test pieces. The die-part interface rig configuration set up for the ceramic material trials is shown in Figure 1.

\subsection{Experiment procedure}

The trials included a series of thermo-mechanical cycle loads at standard Superplastic forming conditions. The aim of the experiments was to assess the wear behaviour of the ceramic materials under investigation when subjected to Superplastic forming representative conditions. The key metrics for the assessment were:

- $\quad$ resistance to thermal cycles (cracking)

- die surface degradation

- $\quad$ titanium scale accumulation.

The geometry of the ceramic dies used for the trials is shown in Figure 2(a). The die was a $50 \times 50 \times 50 \mathrm{~mm}$ cube with square surface of $2500 \mathrm{~mm} 2$ for the application of the load. The ceramic die is supported and kept in place by a metallic holder as shown in Figure 2(b). The top die (manufactured with HR4 Cronite) is a solid cylinder of $80 \mathrm{~mm}$ diameter with a uniform flat surface.

A titanium sheet was used as the forming part and was placed between the two dies during the trials. The titanium sample was made of commercial Ti-6Al-4V alloy with rectangular dimensions $40 \times 60 \times 1.2 \mathrm{~mm}$.

\subsection{Design of experiments}




\section{WILEY-VCH}

The three materials selected were tested (standard mechanical tests) at high temperatures (over $850^{\circ} \mathrm{C}$, standard superplastic forming temperature), in order to compare their mechanical properties.

Following by tests of the ceramic cubes carried out using the die-part interface rig under Superplastic forming conditions with a representative Superplastic forming tooling temperature of over $850^{\circ} \mathrm{C}$. A static compressive load was applied to the titanium sample placed between the bottom ceramic die and the top metallic die. The total set of experiments included:

- $\quad 25$ parts at $2 \mathrm{MPa}$ (comparable to Superplastic forming batch production);

- $\quad 25$ parts at $3 \mathrm{MPa}$ (comparable to Superplastic forming batch production);

- $\quad 2 \mathrm{~h}$ cycles (simulated forming time of one part);

- $\quad 50 \mathrm{~h}$ of compressive load per ceramic material (comparable to the expected lifespan of ceramic tools).

The total test time for each ceramic material simulated a typical lifespan of a ceramic Superplastic forming die.

A parting agent, boron nitride, was applied to each Ti-6Al-4V sample to avoid that the sample sticks to the die surface. For the first 13 samples tested with the metallic fibre reinforced ceramic material die, boron nitride in halogen free solvents (DAG 5711) was applied. However this parting agent combusted at high temperatures. Therefore, from sample 14 onwards and the rest of the trials, boron nitride and bentonite dispersed in water (Kennametal WJMB) was used. 


\section{WILEY-VCH}

\subsection{Characterisation method}

The mechanical properties of the selected materials were first compared based on their behaviour over $850{ }^{\circ} \mathrm{C}$. Then, during and after the ceramic die tests on the diepart interface rig, Staiano, A., et al. [14] experimental protocol for wear assessment of hot forming die surfaces was followed.

Each ceramic die material was visually inspected before and after the die-part interface rig trials. An Infinite Focus Confocal Microscope (Alicona) was used to obtain a topography of the die surface and measure the die and metal sample surface roughness. The measurements were taken with a $5 x$ magnification objective, with $400 \mathrm{~nm}$ and $55.99 \mu \mathrm{m}$ as vertical and lateral resolution respectively. Additionally, the presence of wear and titanium accumulation on the ceramic die surface was investigated in situ through thermal camera imaging during the trials. The surface condition of the titanium samples were expected to mirror the die wear, hence their surface roughness growth was also analysed as function of the number of cycles.

\section{Material Behaviour under Common Superplastic forming conditions}

\subsection{Resistance to Thermal Cycles (cracking)}

A comparison of the mechanical properties of the freeze-cast reinforced ceramic material, the particle reinforced ceramic material, and the metallic fibre reinforced ceramic material is presented in Table 1. These materials were tested (standard mechanical tests) at room temperature and at high temperatures (over $850^{\circ} \mathrm{C}$ ).

From the analysis of the data, it is evident that the freeze-cast reinforced ceramic material has higher bending failure stress $(18 \mathrm{MPa})$ than the particle reinforced 


\section{WILEY-VCH}

ceramic material (2.3 MPa), but lower than the metallic fibre reinforced ceramic material (22 MPa). The metallic fibre reinforced ceramic material has more resistance than the others to compression loads, however the density of this material is $30 \%$ higher than the other two.

During the standard mechanical tests, the freeze-cast reinforced ceramic material behaved in a much more brittle fashion than the particle reinforced ceramic material and the metallic fibre reinforced ceramic material. The load-displacement curve of the freeze-cast reinforced ceramic material exhibited a steep, linear slope to the point of failure, whereas the load-displacement curve for the particle reinforced ceramic material had relatively shallow gradients and distinct curvature towards the peak load. The latter is usually indicative of plasticity and in this case it could be due to bulk elastic deformation of the particle reinforced ceramic material, i.e. reinforcement particles moving under load as the material became damaged. The metal hook fibres in the metallic fibre reinforced ceramic material give flexibility to the ceramic. However, too much flexibility in the tool is unfavourable for Superplastic forming dies, as the part could not be formed with the correct geometry due to possible deformations in the die.

Thermal expansion is other parameter to be considered in Superplastic forming dies. The freeze-cast reinforced ceramic material and particle reinforced ceramic material present a very low coefficient of thermal expansion, which can be considered negligible in comparison with metallic dies. By contrast, the metallic fibre reinforced ceramic material exhibited a higher coefficient of thermal expansion, which was still 


\section{WILEY-VCH}

lower than typical values in metallic dies but high enough to require careful consideration in die design (dimensional tolerances).

The materials under investigation went then through a series of trials to assess their wear under Superplastic forming conditions using the Advanced Forming Research Centre die-part interface rig. A static compressive load was applied on the titanium sheet placed between the bottom ceramic die and the top metallic die to reproduce the die-part interaction during the SPF process. The trials were carried out at pressures of $2 \mathrm{MPa}$ ( $3 \mathrm{kN}$ applied load on the sample area) and $3 \mathrm{MPa}$ ( $5 \mathrm{kN}$ applied load on the sample area) and common Superplastic forming temperatures. During the trials, the ceramic dies were cyclically loaded and unloaded, and cyclically heated and cooled; hence they underwent thermomechanical cycles which generate thermal stresses within the material. These stresses might had caused cracking of the die.

The scanned surfaces of the particle reinforced ceramic material, $\mathrm{F}$ and $\mathrm{M}$ dies, before and after of the trials at $3 \mathrm{MPa}$ are presented in Figure 3. The images were taken with the Alicona microscope. A boron nitride layer attached (partially or completely) to the surface of the dies can be observed. However, no evidence of cracking was found in any of the dies. A broken section of the surface of the particle reinforced ceramic material die can be observed in Figure 3. This is due to the titanium sample being stuck to the surface of the ceramic die after the trials, and the surface getting damaged when released. Also, a small area in the bottom corner of the metallic fibre reinforced ceramic material die seems to be broken, however the edges of the die were not uniform from the start of the trials and the size of the defect did not increase during the tests. 


\section{WILEY-VCH}

\subsection{Die Surface Degradation}

The quality of superplastic formed parts also depends on the conditions of the die surface. The most common quality defects are on scratches, lubricant built up, and excessive roughness [14]. Following Staiano, A., et al. [14] experimental protocol, the presence of wear on the ceramic die surface was investigated in situ through thermal camera imaging and by microscopy imaging. Furthermore, wear was estimated by assessing the surface roughness of the die before and after the trials.

A parting agent, boron nitride, was applied to each Ti-6Al-4V sample before the trials. The die surface generally suffers from boron nitride oxidation during the Superplastic forming process. When boron nitride oxidizes, the titanium sample might stick to the die surface. The removal of the titanium sample might generate local cracks which propagate with the surface of the die at each Superplastic forming cycle, resulting in spalling of the superficial ceramic particles. The cracks generate poor quality of the final part and die surface degradation (reduction of the die lifespan). Moreover, the cracks could propagate within the die and in extreme cases may cause catastrophic failure of the die.

The thermal images of the ceramic die surface are presented in Figure 4. The images are in grey scale and the deviation in colour represents a change in the quality of the surface and/or titanium adhesion. The particle reinforced ceramic material die tested under low pressure (2 MPa) is presented in Figure 4(a). The die shows wear in terms of small voids due to fine particles removed from its surface and a small amount of boron nitride transferred from the work piece to the die which caused the trials to be 


\section{WILEY-VCH}

interrupted after 15 cycles. The particle reinforced ceramic material die tested at higher pressure (3 MPa) is shown in Figure $4(\mathrm{~b})$. Boron nitride oxidation is visible highlighted with arrows - on the ceramic surface (oxidation-like scale). When boron nitride oxidised, the work piece stuck to the die surface which broke when the part was released, resulting in low quality of the final part and wear of the die after 10 cycles. The metallic fibre reinforced ceramic material die after 25 cycles at $2 \mathrm{MPa}$ is shown in Figure 4(c). It can be observed that there is no evidence of die surface damage. The metallic fibre reinforced ceramic material die after 25 cycles at 3 [MPa] is shown in Figure 4(d),; no evidence of surface damage (cracking) can be observed; however the adhesion of boron nitride is evident. This boron nitride layer may cause defects in the superplastically formed part.

The last step from Staiano, A., et al. [14] experimental protocol was the analysis of the titanium samples after undergoing to the Superplastic forming tests. It was expected that the titanium samples would have mirrored the surface quality of the ceramic die. As anticipated, all titanium samples exhibited high temperature oxidation and some residual boron nitride oxide attached to their surface. The titanium sample surface roughness $(\mathrm{Sa})$ as a function of the number of cycles is presented in Figure 5 (a logarithmic scale for the number of cycles was used for clarity).

The results show that the samples formed with the freeze-cast reinforced ceramic material exhibited a stable surface roughness for the first 8 cycles at low pressure (2 $\mathrm{MPa})$ and for the first 6 cycles at high pressure $(3 \mathrm{MPa})$. At high pressure, the roughness of the samples tested with the particle reinforced ceramic material die increased considerably after 3 cycles, indicating a significant wear of the ceramic die 


\section{WILEY-VCH}

surface. At low pressure for the same die material, the roughness increased at a smaller rate, indicating a smaller surface wear. It can be also observed that for the samples formed by the metallic fibre reinforced ceramic material die, the surface roughness remained stable for the first 25 cycles at $2 \mathrm{MPa}$. When the pressure increased to $3 \mathrm{MPa}$, the surface roughness remained stable for 15 cycles, then started increasing exponentially during the last 10 samples. This trend is an indication of the degradation of the surface finish of the die, which could be due to the attachment of boron nitride to the surface.

The surface integrity of the dies was also evaluated in terms of number of parts formed. According to Staiano, A., et al. [14], the surface quality of the freeze-cast reinforced ceramic material die was acceptable to form up to 8 samples at $2 \mathrm{MPa}$ and 6 samples at $3 \mathrm{MPa}$, the particle reinforced ceramic material can remain suitable up to 4 samples at $2 \mathrm{MPa}$ and 3 samples at $3 \mathrm{MPa}$, and the metallic fibre reinforced ceramic material lasted up to 25 samples at $2 \mathrm{MPa}$ and 15 samples at $3 \mathrm{MPa}$.

In is important to observe, that for the first 13 samples tested with the metallic fibre reinforced ceramic material die, when the boron nitride in halogen free solvents (DAG 5711) lubricant was applied, the surface roughness remained stable, and the samples did not become stuck to die surface. From sample 14, boron nitride and bentonite dispersed in water (Kennametal WJMB) lubricant was used and the samples tended to stick to the die. The boron nitride attachment did not seem to have a significant effect on the ceramic die surface quality but seems to affect the ease of removing the titanium samples (with resulting of risk of cracking). The use of a 


\section{WILEY-VCH}

coating on the die surface or a different releasing agent could reduce drastically the adhesion of the titanium piece to the die, therefore increasing the die life.

\subsection{Titanium Scale Accumulation}

The adhesion of titanium to the die surface is a known cause of defects and dimensional variations in superplastically formed parts. The thermal images recorded during the trials (Figure 4) were used to monitor in situ the die surface degradation and titanium adhesion. The change in colour in the thermal images represents a change in the quality of the surface condition and/or titanium adhesion. Titanium oxide can be observed in the particle reinforced ceramic material die at high pressure (Figure 4(b)) which is in agreement with the Alicona images (Figure 3). Similarly, as expected from the Alicona images, there is no titanium accumulation on the metallic fibre reinforced ceramic material die surface (Figure 4(c) and (d)).

\section{Conclusion}

In this work, the problem of high cost tooling for superplastic forming was addressed by the Advanced Forming Research Centre. The overall objective of this work was to expand the research in low cost die materials for Superplastic Forming processes. The reduction in cost of the Superplastic forming process may promote its wider use in the industry and reduce the production cost for the current users. Ceramic dies demonstrated to be a viable solution and reinforcement can be used as an alternative option to significantly reduce their tendency surface damage and bulk failure. Three commercial reinforced ceramic materials; a freeze-cast reinforced ceramic, a particle reinforced ceramic, and a fibre reinforced ceramic were mechanically tested with the aim of evaluate their wear behaviour when undergoing testing at Superplastic forming 


\section{WILEY-VCH}

representative conditions and assessing their viability for the manufacture of Superplastic forming dies.

Results show that in compression, flexural and fracture toughness, the freeze-cast reinforced ceramic material and the metallic fibre reinforced ceramic material performed better than the particle reinforced ceramic material, but the freeze-cast reinforced ceramic material exhibited classical brittle behaviour while the particle reinforced ceramic material dissipated damage throughout the structure in a more efficient manner (safer dies). The freeze-cast reinforced ceramic material and the metallic fibre reinforced ceramic material have considerably lower thermal conductivity, which has cost implications for heating time and Superplastic forming cycle time. The metallic fibre reinforced ceramic material has significantly high thermal expansion in comparison with the particle reinforced ceramic material and the freeze-cast reinforced ceramic material, hence higher dimensional tolerances are required. In all cases, the surface quality was degraded due to boron nitride adhesion. The use of a coating on the die surface or a different parting agent could reduce drastically the adhesion of the work piece and the die, therefore increasing the die life.

The results presented here also illustrates how thermal images can help to identify surface wear after removal of Ti-6Al-4V parts. This technology could be easily implemented into a manufacturing environment to monitor surface wear of ceramic dies in situ. Moreover, this work has been developed using a low cost method for comparing hot forming tool materials. This method could be used for assessing other metallic and ceramic materials. 


\section{WILEY-VCH}

\section{Acknowledgements}

The authors wish to acknowledge financial support for this work from the AFRC Tier 1 membership through the Core research programme

\section{References}

[1] G. Bernhart, P. Lours, T. Cutard, V. Velay, and F. Nazaret, Superplastic Forming of Advanced Metallic Materials 3 Process and equipment for superplastic forming of metals. Elsevier, 2011.

[2] D. G. Sanders, "Reinforced Ceramic Dies for Superplastic Forming Operations," J. Mater. Eng. Perform., vol. 13, no. 6, pp. 753-757, Dec. 2004. [3] C. Y. Gao, P. Lours, and G. Bernhart, "Thermomechanical stress analysis of superplastic forming tools," J. Mater. Process. Technol., vol. 169, no. 2, pp. 281-291, Nov. 2005.

[4] A. Jocelyn, T. Flower, and D. Nash, "Generic Ceramic Tooling (GenCerT) for the SPF/DB Process," Mater. Sci. Forum, vol. 357-359, pp. 2328, 2001.

[5] S. S. Jiang and K. F. Zhang, "Study on controlling thermal expansion coefficient of $\mathrm{ZrO} 2-\mathrm{TiO} 2$ ceramic die for superplastic blow-forming high accuracy Ti-6Al-4V component,” Mater. Des., vol. 30, no. 9, pp. 3904-3907, Oct. 2009.

[6] V. Velay, G. Bernhart, A. Martinier, and J. Y. Moraux, "High Temperature Fatigue of SPF Die Ni-Cr-Fe Heat Resistant Nickel-Chromium Cast Steels," Key Eng. Mater., vol. 433, pp. 69-76, Jun. 2010. 


\section{WILEY-VCH}

[7] D. G. Sanders, "A Production System Using Ceramic Die Technology for Superplastic Forming," Mater. Sci. Forum, vol. 447-448, pp. 153-158, 2004.

[8] D. François, A. Pineau, and A. Zaoui, Mechanical Behaviour of Materials, vol. 191. Dordrecht: Springer Netherlands, 2013.

[9] G. Yaofu, G. Naicheng, Z. Daren, and H. Mancai, "The superplastic forming of metal sheets using a die of refractory concrete," J. Mater. Process. Technol., vol. 30, no. 2, pp. 159-166, Mar. 1992.

[10] D. Sanders, "Integral forming die system for superplastic metal forming," US 5467626 A, 1995.

[11] G. Bernhart, F. Nazaret, and T. Cutard, "Fibre Reinforced Refractory Castables :An Alternative Solution for SPF Die Manufacturing," Mater. Sci. Forum, vol. 551-552, pp. 37-42, 2007.

[12] G. Bernhart, F. Nazaret, and T. Cutard, "Low cost refractory castable die development for titanium sheet superplastic forming," in 7th Brazilian Congress on Manufacturing Engineering, 2013.

[13] Y. Deng, W. Li, R. Wang, J. Shao, P. Geng, and J. Ma, “The temperature-dependent fracture models for fiber-reinforced ceramic matrix composites," Compos. Struct., vol. 140, pp. 534-539, Apr. 2016.

[14] A. Staiano, W. Ion, and L. O'Hare, "Analysis of ceramic surface before and after test," in Proceeding of the 23rd CAPE Conference, 2015.

[15] G. Bernhart, F. Nazaret, and T. Cutard, "Fiber reinforced refractory castables for SPF toolings," Materwiss. Werksttech., vol. 39, no. 4-5, pp. 317321, Apr. 2008.

[16] Aurock, "AUR-01/FH15 datasheet," Albi, France, 2016. 


\section{WILEY-VCH}

[17] MatWeb, "MatWeb, Material Property Data," 2016. [Online]. Available: http://www.matweb.com/index.aspx.

Received in final form: ((will be filled in by the editorial staff)) 


\section{WILEY-VCH}

Table 1 Mechanical characteristics of the three ceramic materials under investigation [15]-[17]

\begin{tabular}{|c|c|c|c|c|c|c|}
\hline \multirow[t]{3}{*}{ Test description } & \multicolumn{2}{|c|}{$\begin{array}{l}\text { Freeze-cast } \\
\text { reinforced } \\
\text { ceramic material }\end{array}$} & \multicolumn{2}{|c|}{$\begin{array}{l}\text { Particle } \\
\text { reinforced } \\
\text { ceramic material }\end{array}$} & \multicolumn{2}{|c|}{$\begin{array}{l}\text { Metallic fibre } \\
\text { reinforced } \\
\text { ceramic } \\
\text { material }\end{array}$} \\
\hline & \multicolumn{2}{|c|}{$1830 \mathrm{~kg} / \mathrm{m}^{3}$} & \multicolumn{2}{|c|}{$2109 \mathrm{~kg} / \mathrm{m}^{3}$} & \multicolumn{2}{|c|}{$3000 \mathrm{~kg} / \mathrm{m}^{3}$} \\
\hline & $R T$ & $930^{\circ} \mathrm{C}$ & $R T$ & $930^{\circ} \mathrm{C}$ & Low $T$ & $\operatorname{High} T$ \\
\hline $\begin{array}{l}\text { Bending failure } \\
\text { stress [MPa] }\end{array}$ & 10.91 & 18.16 & 3.67 & 2.29 & 19 & 22 \\
\hline $\begin{array}{l}\text { Compression } \\
\text { failure stress } \\
\text { [MPa] }\end{array}$ & 50.8 & 77.27 & 45.14 & 45.25 & 95 & 100 \\
\hline $\begin{array}{l}\text { Thermal } \\
\text { conductivity } \\
{[W / m K]}\end{array}$ & 4.2 & 2.52 & 11.73 & 4.08 & 3.14 & 3.01 \\
\hline $\begin{array}{l}\text { Maximal strength } \\
\text { [MPa] }\end{array}$ & 0.99 & 1.94 & 0.59 & 0.93 & 17 & 21 \\
\hline \multirow{2}{*}{$\begin{array}{l}\text { Thermal } \\
\text { expansion }\left[/{ }^{\circ} \mathrm{C}\right]\end{array}$} & \multicolumn{2}{|c|}{ Cast: $1.9 \times 10^{-6}$} & \multicolumn{2}{|c|}{ Cast: $1.74 \times 10^{-6}$} & \multicolumn{2}{|l|}{$8 \times 10^{-6}$} \\
\hline & \multicolumn{2}{|c|}{$\begin{array}{l}\text { Transverse: } 1.82 \times 1 \\
0^{-6}\end{array}$} & \multicolumn{2}{|c|}{$\begin{array}{l}\text { Transverse: } \\
2.61 \times 10^{-6}\end{array}$} & & \\
\hline
\end{tabular}




\section{WILEY-VCH}

Figure 1 DPI rig configuration for the ceramic die trials.

Figure 2 Ceramic die geometry for the trials in the DPI rig. (a) Ceramic cube. (b) Die holder.

Figure 3 Surface scan of the ceramic dies: freeze-cast reinforced ceramic material (left), particle reinforced ceramic material (right) and metallic fibre reinforced ceramic material (centre) before (top row) and after (bottom row) the trials.

Figure 4 Thermal images of the ceramic dies for (a) particle reinforced ceramic material after 15 cycles at 2 [MPa], (b) particle reinforced ceramic material after 10 cycles at 3 [MPa], (c) metallic fibre reinforced ceramic material after 25 cycles at 2 [MPa], and (d) metallic fibre reinforced ceramic material after 25 cycles at 3 [MPa]. Thermal imaging was used to identify surface wear after removal of Ti-6AI-4V parts.

Figure 5 Surface roughness $(\mathrm{Sa})$ of the titanium samples as a function of the number of cycles (logarithmic scale). 